\title{
REFINEMENTS OF BOUNDS FOR NEUMAN MEANS IN TERMS OF ARITHMETIC AND CONTRAHARMONIC MEANS
}

\author{
WEI-MAO QIAN AND YU-Ming CHU
}

Abstract. In this paper, we present the sharp upper and lower bounds for the Neuman means $S_{A C}$ and $S_{C A}$ in terms of the the arithmetic mean $A$ and contraharmonic mean $C$. The given results are the improvements of some known results.

Mathematics subject classification (2010): 26E60.

Keywords and phrases: Schwab-Borchardt mean, Neuman mean, arithmetic mean, contraharmonic mean.

\section{REFERENCES}

[1] E. Neuman And J. SÁndor, On the Schwab-Borchardt mean, Math. Pannon., 2003, 14 (2): $253-$ 266.

[2] E. Neuman And J. SÁndor, On the Schwab-Borchardt mean II, Math. Pannon., 2006, 17 (1): 4959.

[3] H. LiU And X.-J. Meng, The optimal convex combination bounds for Seiffert's mean, J. Inequal. Appl., 2011, Article ID 686834, 9 pages.

[4] W.-D. JIANG AND F. QI, Some sharp inequalities involving Seiffert and other means and their concise proofs, Math. Inequal. Appl., 2012, 15 (4): 1007-1017.

[5] W.-D. JIANG, Some sharp inequalities involving reciprocals of the Seiffert and other means, J. Math. Inequal., 2012, 6 (4): 593-599.

[6] Y.-M. ChU, M.-K. WANG AND Z.-K. WANG, Best possible inequalities among harmonic, geometric, logarithmic and Seiffert means, Math. Inequal. Appl., 2012, 15 (2): 415-433.

[7] E. Neuman, A note on a certain bivariate mean, J. Math. Inequal., 2012, 6 (4): 637-643.

[8] E. Neuman, On one-parameter family of bivariate means, Aequations Math., 2012, 83 (1-2): 191197.

[9] E. Neuman, A one-parameter family of bivariate means, J. Math. Inequal., 2013, 7 (3): 399-412.

[10] E. Neuman, Inequalities involving certain bivariate means II, J. Inequal. Spec. Funct., 2013, 4 (4): $12-20$.

[11] E. Neuman, Sharp inequalities involving Neuman-Sándor and logarithmic means, J. Math. Inequal., 2013, 7 (3): 413-419.

[12] E. NEUmAn AND J. SÁNDOR, Bounds for the quotients of differences of certain bivariate means, Adv. Stud. Contemp. Math., 2013, 23 (1): 61-67.

[13] W.-M. QIAN AND Y.-M. CHU, Optimal bounds for Neuman means in terms of geometric, arithmetic and quadratic means, J. Inequal. Appl., 2014, 2014: 175, 13 pages.

[14] Z.-H. YANG, Y.-Q. SONG AND Y.-M. ChU, Monotonicity of the ratio of the power and second Seiffert means with applications, Abstr. Appl. Anal., 2014, Article ID 840130, 4 pages.

[15] Y.-M. ChU AND W.-M. QIAN, Refinements of bounds for Neuman means, Abstr. Appl. Anal., 2014, Article ID 354132, 8 pages.

[16] S.-B. Chen, Z.-Y. He, Y.-M. ChU, Y.-Q. Song AND X.-J. TAO, Note on certain inequalities for Neuman means, J. Inequal. Appl., 2014, 2014: 370, 10 pages.

[17] Z.-J. GuO, Y.-M. ChU, Y.-Q. Song AND X.-J. TAO, Sharp bounds for Neuman means by harmonic, arithmetic, and contraharmonic means, Abstr. Appl. Anal., 2014, Article ID 914242, 8 pages. 
[18] Y. Zhang, Y.-M. ChU AND Y.-L. JiAnG, Sharp geometric mean bounds for Neuman means, Abstr. Appl. Anal., 2014, Article ID 949815, 6 pages.

[19] E. Neuman, On generalized Seiffert means, Aequationes Math., 2014, 87 (3): 325-335.

[20] E. Neuman, On a new bivariate mean, 2014, 88 (3): 277-289.

[21] E. Neuman, On some means derived from the Schwab-Borchardt mean, J. Math. Inequal., 2014, 8 (1): 171-183.

[22] E. Neuman, On some means derived from the Schwab-Borchardt mean II, J. Math. Inequal., 2014, 8 (2): 359-368.

[23] Z.-Y. HE, Y.-M. CHU AND M.-K. WANG, Optimal bounds for Neuman means in terms of harmonic and contraharmonic means, J. Appl. Math., 2013, Article ID 807623, 4 pages.

[24] Y.-M. Chu, H. WAng AND T.-H. ZhaO, Sharp bounds for the Neuman mean in terms of the quadratic and second Seiffert means, J. Inequal. Appl., 2014, 2014: 299, 14 pages. 